\title{
PENERAPAN METODE TUTOR SEBAYA UNTUK MENINGKATKAN HASIL BELAJAR PENDIDIKAN AGAMA HINDU PADA SISWA KELAS III SEKOLAH DASAR NEGERI 1 SUKADANA
}

\author{
Oleh \\ Ni Luh Adi Palistini \\ Sekolah Dasar Negeri 1 Sukadana \\ adipalistini@gmail.com
}

Diterima 17 Desember 2017, direvisi 28 Januari 2018, diterbitkan 28 Pebruari 2018

\begin{abstract}
The purpose of this study is: to know the results of student learning through the application of Peer Tutor method in grade 3 students of Primary School Negeri 1 Sukadana.Penelitian is Classroom Action Research conducted in two cycles, each consisting of four stages: planning, observation, reflection. The research subjects are the third grade students of SD Negeri 1 Sukadana which amounted to 24 people.

The method used is a test method to collect data on student learning outcomes. After all collected, the data is analyzed descriptively quantitative. Data analysis in this research using quantitative descriptive. The results showed the students' learning outcomes in the first cycle average score of learning outcomes with low categories. The average value of student learning outcomes in the first cycle is 77.08 with $66.66 \%$ classical completeness, absorption $77.08 \%$. Then on the second cycle has increased, the average learning outcome becomes 82.29 classical completeness to $91.66 \%$ and absorption to $82.29 \%$. And result of analysis of learning result of cycle I and II have increase of average value of result of learning equal to 5,21 classical completeness equal to $25 \%$ absorption equal to 5,21\% with use of peer tutor method.

Based on the results of this study can be concluded the use of peer tutors can improve learning outcomes Hindu Religious Education. (1) Hindu Education Teachers to try to apply the use of peer tutors (2) Other researchers are expected to conduct further research related to the application of innovative learning models.
\end{abstract}

Keywords: Peer Tutor, Learning Outcomes. 


\section{PENDAHULUAN}

Pembelajaran adalah proses interaksi peserta didik dengan guru dan sumber belajar pada suatu lingkungan belajar. Proses pembelajaran perlu direncanakan, dilaksanakan, dinilai, dan diawasi agar dapat terlaksana secara efektif dan efesien. Mengingat kebhinekaan budaya, keragaman latar belakang dan karakteristik peserta didik, serta tuntutan untuk menghasilkan lulusan yang bermutu, proses pembelajaran untuk setiap mata pelajaran harus fleksibel, bervariasi, dan memenuhi standar.

Namun kenyataannya, terkadang guru Pendidikan Agama Hindu mengalami kesulitan dalam mengaktifkan siswa secara merata karena kemampuan yang dimiliki oleh setiap siswa tidaklah sama. Oleh karena itu, hanya siswa yang memiliki kemampuan tinggi yang menguasai kelas, sedangkan siswa lainnya pasif, dan persentase siswa pasif lebih banyak daripada siswa yang aktif. Hal itu berdampak pada hasil belajar siswa yang secara klasikal belum memenuhi KKM yang ditargetkan. Hal seperti itu terjadi pada siswa kelas III Sekolah Dasar Negeri 1 Sukadana. Aktivitas siswa dalam kegiatan pembelajaran cenderung hanya menyimak dan mencatat. Kalau pun ada halhal yang kurang jelas, hanya beberapa siswa yang mau bertanya. Hal Akhirnya, pada saat diberikan tes, hasilnya secara klasikal berada di bawah KKM, yakni 69 padahal KKM-nya adalah 73. Pada akhirnya, hal tersebut akan berimplikasi pada aktivitas belajar siswa yang optimal dan hasil belajar siswa sesuai harapan. Keberhasilan siswa dalam proses pembelajaran di sekolah ditunjukkan dengan prestasi belajar yang dicapai merupakan akumulasi dari beberapa faktor yang satu dengan yang lainnya saling berkaitan. Proses pembelajaran di sekolah bersifat komplek, karena di dalamnya terdapat aspek pedagogik, psikologis dan didaktik.

Solusi yang dipilihuntuk mengatasi masalah rendahnya keaktifan dan hasi belajar siswa adalah dengan penerapan metode tutor sebaya.
Metode tutor sebaya efekif diterapkan karena melalui metode tutor sebaya siswa dapat meningkatkan keterlibatannya dalam kegiatan pembelajaran melalui bimbingan yang diberikan oleh teman sejawatnya. Jika siswa menemukan sendiri pengetahuan itu melalui pembimbingan teman sejawat, siswa akan memiliki kepuasan tersendiri, baik siswa yang memberikan bimbingan maupun siswa yang dibimbing. Berdasarkan latar belakang masalah di atas, dalam penelitian ini dirumuskan kajian pustaka sebagai berikut; metode tutor sebaya, hasil belajar dan pendidikan agama Hindu

Strategi pembelajaran dengan menggunakan tutor sebaya adalah suatu strategi pembelajaran yang memanfaatkan siswa lain yang memiliki kemampuan lebih tinggi untuk membantu temannya dalam menguasai materi pelajaran yang diajarkan. Siswa yang memiliki kemampuan lebih cepat menyerap materi pelajaran akan membantu siswa yang kurang cepat menyerap materi pelajaran. Bahasa yang digunakan oleh teman sebaya lebih mudah dipahami, selain itu dengan teman sebaya tidak ada rasa segan, rendah diri, malu dan sebagainya sehingga diharapkan siswa yang kurang paham tidak segan-segan untuk mengungkapkan kesulitan-kesulitan yang dihadapi (Suherman,2003: 277).

Inti dari metode pembelajaran tutor sebaya adalah pembelajaran yang pelaksanaannya dengan membagi kelas dalam kelompok-kelompok kecil, yang sumber belajarnya bukan hanya guru melainkan juga teman sebaya yang pandai dan cepat dalam menguasai suatu materi tertentu. Menurut Suryo dan Amin (dalam Ebayanti) menyatakan ada beberapa kelebihan metode tutor sebaya antara lain:

1) Adanya suasana hubungan yang lebih dekat dan akrab antara siswa yang dibantu dengan siswa sebagai tutor yang membantu

2) Peserta didik diajarkan untuk mandiri, setia kawan, dan berpikir dewasa

3) Bagi tutor sendiri kegiatan seperti ini 
merupakan kesempatan untuk memotivasi dirinya belajar lebih giat.

4) Bersifat efesien, artinya bias lebih banyak temannya yang dibantu

5) Dapat meningkatkan rasa tanggung jawab dan kepercayaan diri.

Sedangkan kekurangan atau kelemahan metode tutor sebaya adalah:

1) Siswa yang dipilih sebagai tutor dan berprestasi baik, belum tentu mempunyai hubungan yang baik dengan siswa yang dibantu

2) Siswa yang dipilih sebagai tutor belum tentu bisa menyampaikan materi dengan baik

3) Siswa yang dibantu seringkali kurang serius dalam belajar karena dalam belajar hanya berhadapan dengan temannya sendiri, sehingga hasilnya terkadang kurang memuaskan.

Menurut Dimyati dan Mudjiono hasil belajar sebagai hasil dari suatu interaksi tindakan mengajar atau tidak belajar. menyatakan bahwa: "Hasil belajar terbagi atas tiga ranah, yaitu: kognitif, afektif dan psikomotor". Nitko dan Brookhart (dalam Rasyid, 2008: 2) menyatakan bahwa evaluasi sebagai suatu proses penetapan nilai yang berkaitan dengan kinerja dan hasil karya siswa. Evaluasi merupakan salah satu rangkaian kegiatan dalam meningkatkan kualitas. Dari pendapat para ahli di atas, maka yang dimaksud dengan hasil belajar adalah suatu kemampuan,sikap dan keterampilan yang dimiliki oleh siswa setelah ia mengalami proses belajar dalam kurun waktu tertentu yang dinyatakan dalam bentuk angka atau nilai, sehingga dapat mengkonstruksikan pengetahuannya tersebut dalam kehidupan sehari-hari. Dalam penelitian ini hasil belajar yang di gunakan adalah berupa pengetahuan yang diperoleh dengan metode tes.

Poerbakawatja (dalam Titib,2006: 14) menyatakan arti pendidikan secara luas bahwa pendidikan merupakan usaha orang dewasa untuk mengalihkan pengetahuan, pengalaman, kecakapan, dan keterampilannya kepada generasi muda untuk dapat emenuhi fungsi hidupnya baik jasmani maupun rohani. Darmodiharjo (dalam Titib,2006 :15) mengemukakan bahwa: pendidikan bukan saja hanya berlangsung di sekolah saja melainkan pada semua lingkungan sosialnya, dalam prosesnya itu manusia mendapatkan wawasan, ilmu pengetahuan, keterampilan dari orang lain yang berguna di dalam kehidupannya. Pendidikan Agama Hindu dalam buku Cilakrama disebut dengan istilah Agurongoron. Aguron-guron adalah guru mendidik siswa dengan petunju-petunjuk kerohanian, kebajikan, amal, pengabdian, dan yang berdasarkan dharma serta membekali anak didik dengan berbagai ilmu pengetahuan (Punyatmaja, 1994 :17).

Yang dimaksud dengan pendidikan Agama Hindu adalah suatu proses dan sistem untuk membina pertumbuhan anak didik berdasarkan dharma yang nantinya dapat membentuk moral, etika , spiritual sesuai dengan ajaran Agama Hindu.

Berdasarkan uraian tentang hasil belajar dan pendidikan Agama Hindu maka yang dimaksud dengan hasil belajar pendidikan Agama Hindu adalah suatu kemampuan,sikap dan keterampilan yang dimiliki oleh siswa dalam mata pelajaran Agama Hindu yang berupa nilai serta perubahan tingkah laku dan kepribadian sehingga tercermin adanya peningkatan sradha dan bhakti peserta didik sebagai umat Hindu.

\section{METODE}

\subsection{Rancangan Penelitian}

Rancangan yang digunakan dalam penelitian ini adalah penelitian tindakan kelas (PTK). PTK merupakan penelitian yang bertujuan untuk memberi kontribusi baik sebagai pertimbangan praktis bagi seseorang dalam situasi yang bermasalah di lingkungannya maupun bagi pencapaian tujuan sosial melalui 
kerjasama kolaboratif dalam kerangka etika yang diterima bersama (Rideng, 2001:3).

\subsection{Subyek dan Objek Penelitian}

Dalam penelitian ini, yang menjadi subjek penelitian adalah siswa kelas III Sekolah Dasar Negeri 1 Sukadana tahun pelajaran 2015/2016, yang berjumlah 24 orang, yakni laki-laki 16 orang dan perempuan 8 orang. Sementara itu, Dwija (2006: 14) mengatakan bahwa: "Objek penelitian adalah setiap gejala atau peristiwa yang akan diteliti, baik berupa gejala alam (natural phaenomena), gejala buatan (exsperimental phaenomena), dan dan gejala kehidupan (life phaenomena)". Jadi obyek yang mencerminkan proses dalam penelitian ini adalah metode pembelajaran Tutor Sebaya dalam pembelajaran Pendidikan Agama Hindu, sedangkan obyek yang mencerminkan produk adalah hasil belajar pendidikan Agama Hindu.

\section{PEMBAHASAN PENELITIAN}

HASIL

Langkah awal sebelum pelaksanaan tindakan adalah melakukan observasi. Observasi awal dilakukan dengan mengkaji hasil ulangan harian siswa. Ulangan harian siswa. Ulangan harian yang dilaksanakan mencakup beberapa indikator yang berkaitan dengan materi. Hasil kajian tersebut menunjukkan bahwa hanya ada beberapa siswa yang tuntas dalam pembelajaran, sedangkan sebagian besar siswa yang lain memperoleh nilai di bawah kriteria ketuntasan minimal. Sehingga siswa yang tuntas ini ditunjuk sebagai tutor sebaya. Berdasarkan hasil penelitian menunjukkan bahwa rata- rata hasil belajar siswa kelas II mengalami perubahan yang cukup signifikan mulai dari pra siklus hingga pelaksanaan siklus II.

Pada pra siklus rata-rata hasil belajar siswa sebesar 69,37, kemudian siklus I sebesar 77,08 dan siklus II sebesar 82,29. Itu berarti nilai-rata-rata dari pra siklus sampai siklus I telah mengalami peningkatan sebesar 7,69 dan dari siklus I ke siklus II telah terjadi peningkatan sebesar 5,21. Kemudian daya serap siswa juga mengalami peningkatan dari pra siklus, siklus I dan siklus II. Daya serap siswa pada pra siklus sebesar 69,37\%, siklus I sebesar77,08 \% dan pada siklus II sebesar 82,29 . Berdasarkan data tersebut, dari pra siklus sampai siklus I telah mengalami peningkatan sebesar 7,69\%. Kemudian antara siklus I dengan siklus II mengalami peningkatan sebesar 5,21\%.

Tidak hanya nilai rata-rata siswa dan daya serap saja yang mengalami peningkatan, ketuntasan klasikal juga meningkat. Pada tahap pra siklus ada 10 orang siswa yang tuntas dan 14 siswa yang tidak tuntas. Kemudian siklus I terdapat 16 orang siswa yang tuntas dan 8 orang siswayang tidak tuntas. Selanjunya pada siklus II dari 24 siswa hanya ada 2 orang siswa yang tidak tuntas. Berdasarkan data tersebut ketuntasan klasikal siswa pada tahap pra siklus sebesar 41,66 \%, siklus I 66,66 $\%$ dan pada siklus II sebesar 91,66\%. Oleh karena itu dari pra siklus dan siklus I meningkat sebesar $25 \%$. Sementara dari siklus I ke siklus II terjadi peningkatan sebesar $25 \%$.

Hal ini dapat ditunjukkan ditunjukkan dalam tabel berikut ini.

\begin{tabular}{|c|c|c|c|c|}
\hline No & Jenis Rekapitulasi Data & Tahapan & Nilai & Peningkatan \\
\hline \multirow[t]{2}{*}{1} & \multirow[t]{2}{*}{ Hasil Belajar } & Siklus I & 77,08 & \multirow[t]{2}{*}{5,21} \\
\hline & & Siklus II & 82,29 & \\
\hline \multirow[t]{2}{*}{2} & \multirow{2}{*}{ Daya Serap } & Siklus I & $77,08 \%$ & \multirow[t]{2}{*}{$5,21 \%$} \\
\hline & & Siklus II & $82,29 \%$ & \\
\hline \multirow[t]{2}{*}{3} & \multirow[t]{2}{*}{ Ketuntasan Klasikal } & Siklus I & $66,66 \%$ & \multirow[t]{2}{*}{$25 \%$} \\
\hline & & Siklus II & $91,66 \%$ & \\
\hline
\end{tabular}


Peningkatan nilai rata-rata, daya serap,dan ketuntasan klasikal dari siklus I dengan siklus II karena penerapan metode tutor sebaya pada siklus II lebih optimal. Perbaikannya adalah pada tahap pendahuluan, peneliti memberikan arahan kepada siswa agar lebih serius dalam memperhatikan penjelasan guru, dan pada tahap kegiatan inti peneliti mengganti tutor sebaya yang kurang kompeten dan lebih fokus memberikan perhatian kepada siswa yang kurang aktif dalam proses diskusi dan kepada siswa yang masih suka meniru pekerjaan temannya. Terkait dengan masalah kesiapan siswa, peneliti juga memberikan motivasi dan arahan kepada siswa agar tidak lupa membawa alat pelajaran. Oleh karena itu dalam penerapan metode tutor sebaya hendaknya dilengkapi dengan adanya perhatian yang lebih fokus terhadap siswa dan pemilihan siswa yang menjadi tutor sebaya juga harus tepat.

\section{IV.SIMPULAN}

Berdasarkan hasil penelitian dan pembahasan hasil, maka dapat disimpulkan bahwa penerapan metode tutor sebaya dalam pembelajaran Agama Hindu di kelas III Sekolah Dasar Negeri 1 Sukadana dapat meningkatkan hasil belajar siswa. Hal ini tebukti rata-rata hasil belajar, daya serap siswa, dan ketuntasan klasikal siswa pada siklus I sampai siklus II yang meningkat. Nilai rata-rata siklus I mencapai mencapai 77,08 dan siklus II mencapai 82,29. Itu berarti nilai rata-rata dari siklus I ke siklus II telah terjadi peningkatan sebesar 5,21. Kemudian daya serap siswa pada siklus I sebesar 77,08 \% dan siklus II mencapai 82,29\%. Berdasarkan data tersebut dari siklus I ke siklus II telah terjadi peningkatan sebesar 5,21\%. Ketuntasan klasikal siswa dari siklus I sebesar $66,66 \%$ telah mengalami peningkatan sebesar $25 \%$ menjadi $91,66 \%$. Pada siklus I ada 8 siswa yang tidak tuntas sedangkan pada siklus II hanya ada 2 siswa yang tidak tuntas.

\section{DAFTAR PUSTAKA}

Arikunto,S.1999. Metode Penelitian .Yogyakarta: Pustaka Belajar..

Dwija,W.2006. Metodologi Penelitian Pendidikan (Buku Ajar).Amlapura:STKIP Agama Hindu Amlapura.

Ebayanti,Ida Ayu Wayan. 2015. Penerapan Metode Tutor Sebaya UntukMeningkatkan Hasil Belajar Pendidikan Agama Hindu Pada Siswa Kelas VII A. SMP Negeri 1 Abang.

Mulyasa, 2009. Menjadi Guru Profesional.: Menciptakan Pembelajaran Kreatif Dan Menyenangkan. Bandung : Rineka Cipta.

Nurkancana, Sunartana. 2004. Proses Belajar Mengajar. Bandung : PT Remaja Rosdakarya.

Nurhadi, dkk. 2003. Pembelajaran Kontekstual dan Penerapannya Dalam KBK. Malang : Universitas Negeri Malang.

Punyatmaja, Ida Bagus Oka. 1994.Cilakama. Denpasar : Upada Sastra.

Sudarsana, I. K. (2018, January). Membina Kerukunan Antar Siswa Di Sekolah Melalui Penanaman Pendidikan Budi Pekerti Berbasis Kearifan Lokal. In PROSIDING SEMINAR NASIONAL KEARIFAN LOKAL INDONESIA UNTUK PEMBANGUNAN KARAKTER UNIVERSAL 2015 (pp. 242-250).

Sugiharta, I. P. S. O., \& Sudarsana, I. K. (2017). Hypnotic Learning Characteristics On Sisya Brahmakunta Community In Denpasar. Vidyottama Sanatana: International Journal of Hindu Science and Religious Studies, 1(2), 132-145. 
Titib, M. 2006. Ketuhanan Dalam Weda. Denpasar: Dharma Jati

Wendra, I Wayan. 2009. Buku Ajar Penulisan Karya Ilmiah. Singaraja : Undiksa

Wisarja, I. K., \& Sudarsana, I. K. (2017). REFLEKSI KRITIS IDEOLOGI PENDIDIKAN KONSERVATISME DAN LIBRALISME MENUJU PARADIGMA BARU PENDIDIKAN. Journal of Education Research and Evaluation, 1(4), 283-291.
Wisarja, I. K., \& Sudarsana, I. K. (2017). Praksis Pendidikan Menurut Habermas (Rekonstruksi Teori Evolusi Sosial Melalui Proses Belajar Masyarakat). Indonesian Journal of Educational Research, 2(1), 18-26.

Wulandari, K., \& Sudarsana, I. K. (2017). Eksistensi Pura Ratu Gede Empu Jagat D Desa Sangkaragung Kecamatan Jembrana Kabupaten Jembrana. Jurnal Penelitian Agama Hindu, 1(2), 252-256. 